\title{
Trajno doseganje izvrstnih rezultatov
}

\author{
Dejan Medic* \\ Fakulteta za organizacijske študije v Novem mestu, Ulica talcev 3, 8000 Novo mesto, \\ Slovenija \\ dejan.medic@fos-unm.si \\ Sandra Medic \\ Fakulteta za organizacijske študije v Novem mestu, Ulica talcev 3, 8000 Novo mesto, \\ Slovenija \\ sandra.medic@fos-unm.si
}

\begin{abstract}
Povzetek:
Raziskovalno vprašanje (RV): Kako odlične organizacije dosegajo in trajno ohranjajo izjemne rezultate?

Namen: Ugotoviti s kakšnimi merili in pristopi doseči trajno odlične rezultate, s ciljem ohranjanja izvrstnih rezultatov.

Metoda: Za preučitev je bila uporabljena kvalitativna metoda pregleda domače in tuje literature ter dobrih praks.

Rezultati: $\mathrm{Z}$ raziskavo je bilo potrjeno, da se izjemni rezultati trajno ohranjajo, ob upoštevanju vseh dejavnikov in vključevanju vseh zaposlenih po modelu odličnosti EFQM.

Organizacija: Voditelji razvijajo, določajo, sodelujejo, krepijo in zagotavljajo uspešno obvladovanje sprememb v poslovanju organizacije.

Družba: Odlične organizacije zagotavljajo in ohranjajo izvrstne rezultate, ki zadovoljujejo tako zunanje kot notranje deležnike.

Originalnost: Organizacije za dosego odličnosti ter trajno ohranjanja stanja, ne gledajoč na dejavnost, ki jo opravljajo, bodo posegale po orodjih in modelih poslovne odličnosti.

Omejitve/nadaljnje raziskovanje: Raziskovanje je možno nadgraditi na druge gradnike in model uporabiti v praksi kot implementacijo modela odličnosti EFQM 2013 v organizaciji. V nadaljevanju raziskavo razširiti na model EFQM 2020.
\end{abstract}

Ključne besede: EFQM model odličnosti, temeljna načela odličnosti, merila, dejavniki, rezultati, deležniki, integriteta.

\section{Uvod}

Odličnost, izjemni rezultati so besede, ki si jih vsaka organizacija želi slišati. Ključno za trajno doseganje izvrstnih rezultatov podjetja se prične pri voditeljstvu. 
Odlične organizacije imajo v samem vrhu odlične voditelje. Voditelji razvijajo, določajo, spremljajo, sodelujejo, krepijo poslanstvo, vizijo, vrednote in integriteto $\mathrm{v}$ organizaciji. $\mathrm{Za}$ doseganje izvrstnih rezultatov je potrebno začeti na začetku strukture organizacije in nadaljevati po vseh nivojih. Vsekakor ne smemo pozabiti na ostale t. i. »dejavnike«, ki vključujejo tisto kar organizacija v celoti počne. Na koncu so odraz t. i. »rezultati« in ti so posledica dejavnikov. S povratno zanko, izboljšujemo dejavnike ter posledično rezultate. Povratne informacije kot so: učenje, ustvarjalnost in inovativnost, pomagajo izboljšati dejavnike, ki se odražajo z boljšimi rezultati. (Model odličnosti EFQM, 2013, str. 9)

Najvišji menedžment se mora zavedati, da so spremembe v poslovanju stalnica. Doseči odličnost, izjemnost in vzdrževati odlično stanje, pa je povsem nekaj drugega. Potrebno je veliko vložka in aktivnosti. Hitre izboljšave, jasni pristopi na poslovnih procesih, ohranjanje in spoštovanje pridobljenih vrednot odličnosti, je model na katerem je potrebno graditi.

Namen raziskave je ugotoviti, s kakšnimi pristopi, orodji, merili, doseči odlične in trajne rezultate. S ciljem vzpostaviti ustrezen sistem menedžmenta, ki bo zagotovil skupen cilj, in način komuniciranja, povezave med predlogi, s skupno strukturo sistema. Organizacija s pomočjo modela, oceni kje na poti do odličnosti se nahaja ter poskuša to integriteto nadgraditi in ohraniti.

\section{Teoretična izhodišča}

Trajnostno poslovanje (angl. corporate sustainability), beseda izvira iz trajnostnega razvoja (angl. sustainable development) $\mathrm{v}$ vseh področjih, tako $\mathrm{v}$ okolijskem, družabnem kot $\mathrm{v}$ gospodarskem. Trajnostna poslovna strategija (angl. sustainability strategy) nas usmerja k pravilnem načrtovanju do cilja kar omogoča organizaciji dobre trajnostne rezultate. (Rejc, Hren, Fink, \& Savič, 2018, str.11)

Kako priti do trajno dobrih rezultatov $\mathrm{v}$ organizaciji, Bower in Gilbert (2011, str.1) to opredeljujeta z razlago, kako menedžerji lahko ustvarijo ali uničijo strategijo v organizaciji. Ključno, strategija se mora obvezno ujemati s cilji.

V današnji časih je zelo težko oblikovati zmagovalno strategijo ob številni konkurenci in veliko finančnih pritiskov na trgu. Organizacije prav zaradi tega nimajo potrebnega časa izdelati dobre strategije. Za doseganje trajnih rezultatov morajo organizacije, vzdrževati standarde, se pravilno odločati, iskati vsa dejstva ter upoštevati konkurenco, tako v notranjem kot zunanjem okolju. Organizacije morajo imeti dober strateški načrt, katerega poznajo vsi zaposleni in dobre menedžerje. Zavedati se morajo, da je tok časa zelo hiter in potrebno mu je slediti. (Bertoncelj et all., 2015, str. 20)

Trajnostna uspešnost (angl. sustainability performance), pravimo ji tudi trojček. Trajnostna uspešnost vodi v finančno uspešnost, ki vsebuje okoljsko, družbeno in gospodarsko uspešnost. 
Žal naše organizacije ne razumejo pomen trojčka. Menijo, da morajo skrbeti za zaposlene, kupce in lokalno skupnost. Organizacije morajo skrbeti v širokem pomenu za okolje, družbo in gospodarstvo. (Rejc, Hren, Fink, \& Savič, 2018, str. 11)

$\mathrm{Na}$ trgu lahko pridobimo veliko informacij o trajnostnem doseganju izvrstnih rezultatov. Organizacije imajo v pomoč mnogo različnih modelov, standardov, orodij s katerimi si lahko pomagajo do trajnih izvrstnih rezultatov. Vsekakor morajo biti organizacije zrele na vseh nivojih, za dosego odličnosti.

Eden izmed načinov uspešne organizacije, je vpeljava modela odličnosti EFQM. Model je stavljen iz 8 temeljnih načel odličnosti in 9 meril. Za doseganje meril imamo na razpolago različna orodja, ki nam pomagajo pri doseganju trajnih rezultatov. Orodje, ki je vključeno v model, imenujemo logika RADAR. Logika RADAR je menedžersko orodje s katerim si organizacije lahko pomagajo za doseganje trajnih izvrstnih rezultatov. Pristopi logike RADAR po, Model odličnosti EFQM (2013, str. 22):

- Načrtuj in razvijaj.

- Udejani in razširi.

- Oceni in izboljšaj.

- Rezultati.

EFQM model temelji na temeljnih načelih in so bistvo pri doseganju odličnih rezultatov. Temeljna načela odličnosti po, Model odličnosti EFQM (2013, str. 4):

- Dodajanje vrednosti za odjemalce.

- Ustvarjanje trajnostne prihodnosti.

- Razvijanje sposobnosti organizacije.

- Spodbujanje ustvarjalnosti in inovativnosti.

- Vodenje z vizijo, navdihom in integriteto.

- Agilni management.

- Doseganje uspehov z nadarjenostjo zaposlenih.

- Trajno doseganje izvrstnih rezultatov.

Zadnji kot osmi gradnik temeljnih načel odličnosti, govori o trajnem doseganju izvrstnih rezultatov. Opredeljuje, da »odlične organizacije dosegajo na svojem področju delovanja trajno izvrstne rezultate, ki izpolnjujejo tako kratkoročne kot dolgoročne potrebe vseh njihovih deležnikov« (Model odličnosti EFQM, 2013, str. 8):

- Zbirajo potrebe in pričakovanja deležnikov kot vhodne podatke za razvoj in pregledovanje svoje strategije in podpornih politik, pri tem pa so pozorne na vsako spremembo.

- Prepoznavajo in razumejo ključne rezultate, potrebne za uresničenje svojega poslanstva, ter ovrednotijo napredek glede na svojo vizijo in strateške cilje. 
Marec 2021, leto / year 10, številka / number 1, str. / pp. 69-83.

- Določijo in uporabljajo uravnotežen nabor rezultatov za pregledovanje napredka, zagotavljajo pregled nad dolgo in kratkoročnimi prednostnimi nalogami ter obvladujejo pričakovanja ključnih deležnikov.

- Sistematično udejanjajo in širijo strategijo in podporne politike, da bi dosegli želeni nabor rezultatov, z jasno določenimi vzročno-posledičnimi povezavami.

- Postavljajo cilje na podlagi primerjav svojega delovanja z drugimi organizacijami, na podlagi svojih sedanjih in potencialne organizacijske sposobnosti ter na podlagi svojih strateških ciljev.

- Ovrednotijo nabor doseženih rezultatov, da bi izboljšali uspešnost delovanja v prihodnosti in zagotovili trajne koristi vsem svojim deležnikom.

- Pri deležnikih dosegajo visoko raven zaupanja z uporabo uspešnih mehanizmov za razumevanje prihodnjih scenarijev ter uspešno obvladovanje strateškega, operativnega in finančnega tveganja.

- Zagotavljajo transparentnost pri finančnem in nefinančnem poročanju relevantnim deležnikom, vključno z ustreznim organom upravljanja, v skladu z njihovimi pričakovanji.

- Svojim voditeljem zagotavljajo točne in zadostne informacije v podporo pri njihovem pravočasnem odločanju.

Merila kot jih opredeljuje model odličnosti EFQM, so razdeljena na 5 dejavnikov na levi strani in na 4 rezultate na desni strani kot prikazuje slika 1.

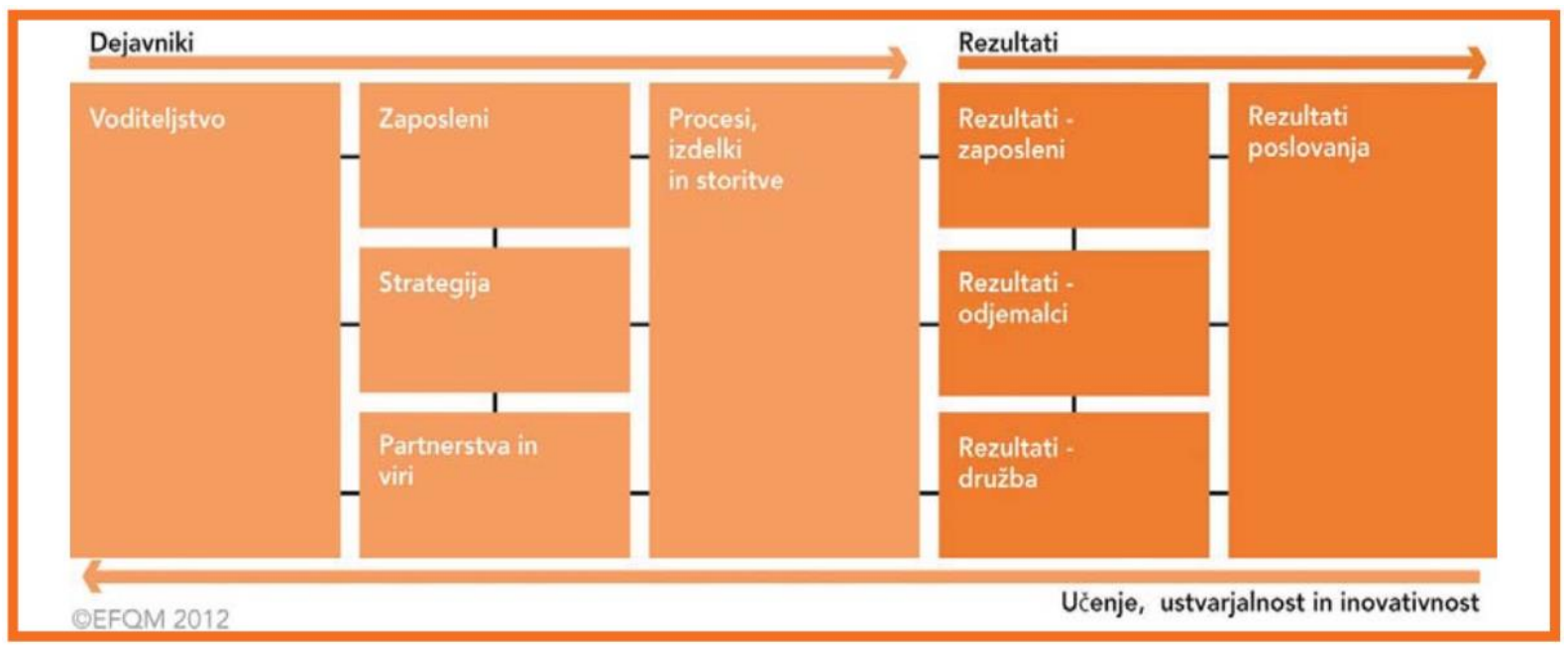

Slika 1. Model odličnosti EFQM 2013. Povzeto iz Model odličnosti EFQM (2013, str. 9).

Dejavniki vključujejo dejanja $\mathrm{v}$ organizaciji in so odraz kar organizacija $\mathrm{v}$ celoti počne. Rezultati so posledica dejavnikov in za trajno doseganje izvrstnih rezultatov je pomembno, stalno učenje, ustvarjalnost ter inovativnost. S povratno zanko popravimo oz. izboljšujemo dejavnike in posledično rezultate. Za uspešno ocenjevanje dejavnikov in rezultatov, uporabimo že prej omenjeno orodje RADAR. (Model odličnosti EFQM, 2013, str. 9-22) 
Revija za univerzalno odličnost / Journal of Universal Excellence,

Marec 2021, leto / year 10, številka / number 1, str. / pp. 69-83.

Kako koristna je vpeljava modela odličnosti EFQM nam prikazujejo analiza, ki se je izvedla s pomočjo anketirancev iz zasebnega in javnega sektorja.

Iz rezultata analize, ponazorjenega na sliki 2, je razvidno, da model odličnosti EFQM v povprečju ocenjuje, Urad RS za meroslovje (2017, str. 15):

- 50 odstotkov anketirancev z oceno odlično 5,

- 41 odstotkov anketirancev s prav dobro 4 in

- 9 odstotkov anketirancev z dobro 3.

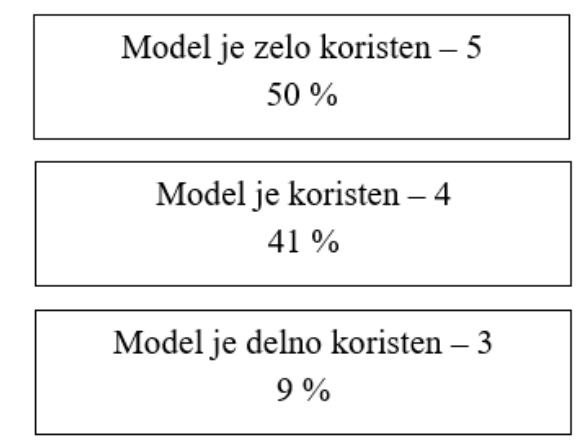

Slika 2. Ocena modela EFQM, za javni in zasebni sektor. Povzeto iz Urad $R S$ za meroslovje (2017, str. 15).

Na sliki 3 je prikazana primerjava ocen modela odličnosti EFQM, med javnim in zasebnim sektorjem. Primerjava je bila narejena na podlagi anketnega vprašalnika, Urad RS za meroslovje (2017, str. 16):

Javni sektor:

- 100 odstotno ocenjuje model EFQM z oceno odlično 5.

Zasebni sektor:

- 60 odstotkov ocenjuje model EFQM z oceno prav dobro 4,

- 27 odstotkov ocenjuje $z$ oceno odlično 5 in

- 13 odstotkov z oceno dobro 3 .
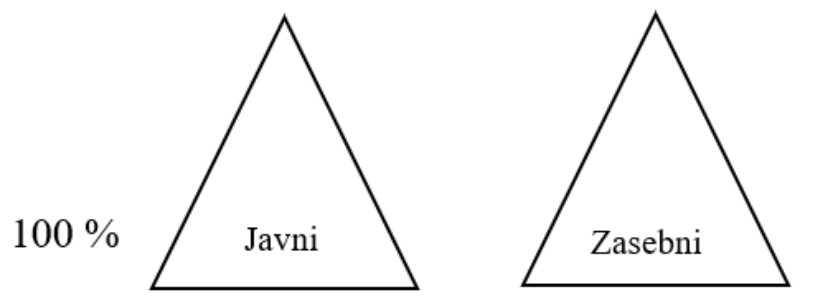

$13 \%$

$27 \%$

$60 \%$

Slika 3. Primerjava ocen med javnim in zasebnim sektorjem.

Povzeto iz Urad RS za meroslovie (2017. str. 15). 
Marec 2021, leto / year 10, številka / number 1, str. / pp. 69-83.

Rezultati za javni in zasebni sektor o sprejetju modela odličnosti EFQM so zelo dobri. Javni in zasebni sektor bi model odličnosti priporočil še ostalim organizacijam. Predvsem zaradi dobrega sistema samoocenjevanja, boljših rezultatov, izmenjava dobrih praks, dviga konkurenčnosti ter dobrih odnosov do družbe in okolja.

\section{Metoda}

Pri raziskovanju vprašanja kako trajno dosegati izvrstne rezultate $\mathrm{v}$ organizaciji, smo uporabili kvalitativno metodo z uporabo modela prikazanega na sliki 4.

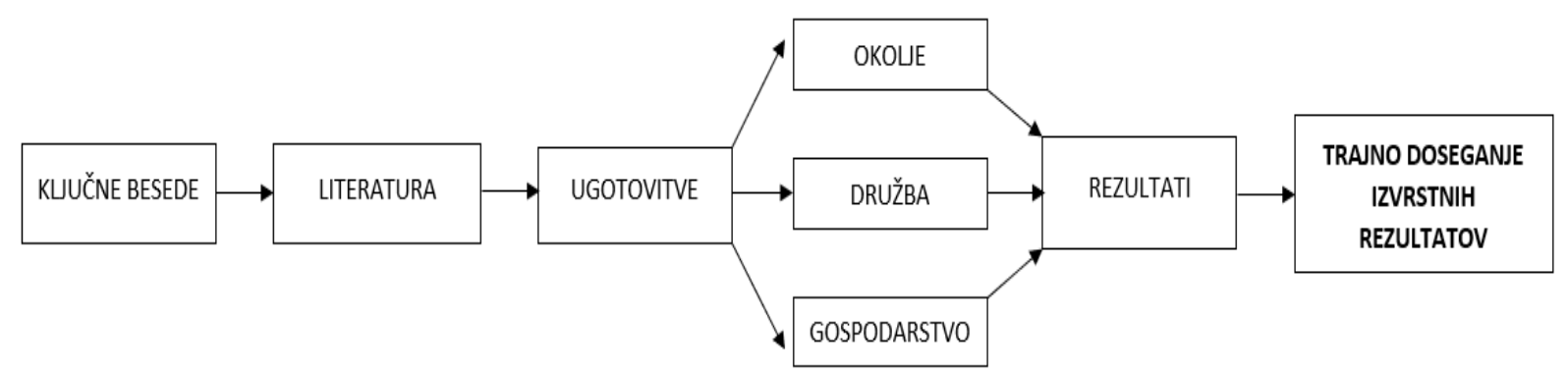

Slika 4. Model raziskave.

Pri iskanju literature smo uporabili ključne besede in poiskali sorodne knjige, članke, magistrska dela, doktorske disertacije, monografije, diplomska dela in ostalo primerno literaturo. Pri raziskavi smo se omejili na literaturo objavljeno v zadnjih desetih letih in to uporabili kot kriterij. V veliko pomoč so nam bili članki revije univerzalne odličnosti. Najbolj pogoste ključne besede po katerih smo izvedli poizvedovanje skozi brskalnik Google učenjak, dLib, so zavedene v tabeli 1.

Tabela 1. Pomembne ključne besede

\begin{tabular}{ll}
\hline \multicolumn{2}{c}{ Pomembne ključne besede } \\
\hline Slovensko poimenovanje & Angleško poimenovanje \\
\hline Trajno doseganje rezultatov & Lasting excellent results \\
Odličnost vodenja & Excellence in leadership \\
Učinkovito poslovanje & Efficient business \\
Uspešno poslovanje & Successful business \\
EFQM model odličnosti & EFQM excellence model \\
Ocenjevanje odličnosti & Assessment of excellence \\
Dejavniki kakovosti & Quality factors \\
\hline
\end{tabular}

$\mathrm{S}$ pomočjo navedenih ključnih besed smo poiskali literaturo, ki je zavedena $\mathrm{v}$ tabeli 2 . $\mathrm{V}$ nadaljevanju smo navedeno literaturo preučili in uporabili v razpravi. 
Revija za univerzalno odličnost / Journal of Universal Excellence,

GRADNIKI POSLOVNE ODLIČNOSTI

Marec 2021, leto / year 10, številka / number 1, str. / pp. 69-83.

Tabela 2. Seznam literature

\begin{tabular}{|c|c|}
\hline Avtor & Naslov \\
\hline Povšnar, M. (2014) & $\begin{array}{l}\text { Dejavniki kakovosti storitev in zadovoljstva uporabnikov: } \\
\text { študija primera v izbrani banki }\end{array}$ \\
\hline Jurša, K. (2015) & Dejavniki odličnosti po modelu EFQM v izbrani banki \\
\hline Štrukelj, T., Krajnović A., \& Peša, A. (2015) & Strateški management za sodobno poslovanje podjetja \\
\hline Jazbec, P. (2012) & Kakovost poslovanja izbranega podjetja \\
\hline Miklavčič, M., \& Rusjan, B. (2018) & $\begin{array}{l}\text { Vloga in pomen meril voditeljstva in ravnanja z zmožnostmi } \\
\text { zaposlenih v modelu EFQM }\end{array}$ \\
\hline Kern, P. K. (2010) & $\begin{array}{l}\text { Vpliv stalnih izboljšav in človeškega kapitala na poslovno } \\
\text { odličnost organizacije }\end{array}$ \\
\hline Škafar, B. (2018) & $\begin{array}{l}\text { Sistemi vodenja kakovosti in modeli odličnosti: ključni } \\
\text { dejavniki (ne)uspešnega podjetja }\end{array}$ \\
\hline Mekiš, A. (2016) & Zavzetost zaposlenih in poslovna odličnost \\
\hline Epstein, M., \& Rejc Buhovec, A. (2010) & Solving the sustainability implementation challenge \\
\hline Krajišnik, U. (2017) & $\begin{array}{l}\text { Ocenjevanje odličnosti poslovanja univerz v Republiki } \\
\text { Sloveniji }\end{array}$ \\
\hline
\end{tabular}

»V raziskovalnem delu članka smo uporabili preglednico ocen FOŠmeter poslovne odličnosti - preglednica ocen, ki povzema rezultate samoocenitve matičnih organizacij udeležencev Poletne šole FOŠ »Poslovna odličnost« in sicer 20 za leto 2018 in 49 za leto 2020 «, FOŠ (2020).

»Samoocenitev poslovne odličnosti je bila izvedena po metodologiji, ki jo je razvila Fakulteta za organizacijske študije v Novem mestu in temelji na modelu odličnosti EFQM. FOŠmeter poslovne odličnosti za vsakega od osmih gradnikov odličnosti podaja opise usmeritvenih trditev, pri čemer je bila za potrebe samoocenitve stopnja doseganja stanja vrednotena $\mathrm{V}$ razponu od 0 do 5 kot to predvideva metodologija modela CAF (angl. Commmon Assesement Framework)«, FOŠ (2020).

\section{Rezultati in razprava}

\subsection{Raziskava gradnika trajno doseganje izvrstnih rezultatov}

$\mathrm{Z}$ raziskavo smo potrdili, da organizacije, ki se poslužujejo orodij kakovosti, so posledično uspešnejše na tržišču. Na temo trajnost, odličnost, uspešnost, itn. smo zasledili veliko literature različnih avtorjev. Iz različnih literatur ter dobrih praks smo povzeli najpomembnejše ugotovitve za trajno doseganje izvrstnih rezultatov, prikazano v tabeli 4. 
Revija za univerzalno odličnost / Journal of Universal Excellence,

GRADNIKI POSLOVNE ODLIČNOSTI

Marec 2021, leto / year 10, številka / number 1, str. / pp. 69-83.

Tabela 1. Najpomembnejše ugotovitve

\begin{tabular}{ll}
\hline Avtor & Najpomembnejše ugotovitve \\
\hline Povšnar, M. (2014) & $\begin{array}{l}\text { V boju za uporabnike si v bankah na različne načine } \\
\text { prizadevajo za pridobivanje novih uporabnikov ter ohran } \\
\text { starih uporabnikov. Zato je kakovost opravljenih bančnih } \\
\text { storitev izrednega pomena za celotno poslovanje bank. }\end{array}$ \\
Jurša, K. (2015) & $\begin{array}{l}\text { Smotri, cilji, merila, kazalniki in standardi uspešnosti v } \\
\text { poslovno-organizacijskem sistemu izhajajo iz vizije in } \\
\text { strategije neke organizacije. }\end{array}$
\end{tabular}

Štrukelj, T., Krajnović A. \& Peša, A. (2015) Da bi dosegli poslovno odličnost, je potrebno odgovorno upravljanje, vodenje in poslovanje podjetja redno usmerjati v inovacije in inovirati.

Jazbec, P. (2012)

Učinkovitost pri doseganju ciljev in učinkovito poslovanje podjetja naj bi bila prva naloga managementa, uspešnost ter uspešno poslovanje pa prva naloga upravljalcev oziroma lastnikov podjetja.

Miklavčič, M., \& Rusjan, B. (2018)

Kern, P. K. (2010)

Škafar, B. (2018)

Mekiš, A. (2016)

Epstein, M., \& Rejc Buhovec, A. (2014)

Krajišnik, U. (2017)
Vodstvo podjetja zagotavlja izboljševanje in prilagodljivost podjetja $\mathrm{z}$ obvladovanjem sprememb ter $\mathrm{s}$ tem skrbi za ustrezno umeščenost podjetja v okolje.

Poslovna odličnost organizacije $=$ vodenje $\mathrm{x}$ človeški kapital $\mathrm{x}$ orodja za stalne izboljšave.

Kreativnost, inovativnost in izvirnost postajajo čedalje pomembnejši dejavniki uspešne poslovne strategije 21 . stoletja.

Ugotovljeno je bilo, da svetovna uspešne organizacije ne uporabljajo samo modele poslovne odličnosti EFQM, temveč tudi različne kombinacije orodij in tehnik upravljanja.

Uskladitev formalnega in neformalnega sistema ter organizacijske strukture je ključnega pomena za uspeh.

Istočasno potrebujejo nenehne stalne inovacije in izboljšave, da bi v okolju, v katerem delujejo, lahko ostale konkurenčne.

Na trgu je veliko konkurence, poglavitno je obdržati in pridobiti nove deležnike. Organizacija to pridobi s kakovostjo opravljanja svojih storitev. (Povšnar, 2014, str. 1)

Vendar, za doseg trajnih izvrstnih rezultatov pot ni enostavna. Kot prvo še vedno velja, da organizacije morajo imeti vizijo, izdelan strateški načrt, ob uporabi primernih orodij, standardov, ki pripomorejo k uspešnosti organizacij. (Jurša, 2015, str. 23) 
Marec 2021, leto / year 10, številka / number 1, str. / pp. 69-83.

Eden izmed najbolj pomembnih vidikov je vodenje. Za dobro "poslovno odličnost « mora biti: vodenje dobro zasnovano, vodeno s popolno odgovornostjo ob upoštevanju vidikov pravega poslovanja. (Štrukelj, Krajnović, \& Peša, (2015, str. 15)

Menedžment je pomemben za »učinkovito poslovanje«, in za »uspešnost poslovanja«. Odgovornost je na lastnikih organizacij. (Jazbec, 2012, str. 22)

Pomembno vlogo ima vodstvo-menedžment organizacije pri doseganju trajno dobrih rezultatov. Ključno je, da se vodstvo $\mathrm{v}$ organizaciji pravilno in pravočasno odzove na spremembe trga. Da so inovativni za nove rešitve. Odgovornost za trajno doseganje izvrstnih rezultatov je na menedžmentu. (Miklavčič \& Rusjan, 2018, str. 99)

Kot bolj zanimiv prispevek, je zapisan s podajanjem formule za doseganje trajnih rezultatov »Poslovna odličnost organizacije = vodenje $\mathrm{x}$ človeški kapital x orodja za stalne izboljšave $«$. Kar pomeni, da vsi trije dejavniki, vplivajo na to, da organizacija doseže trajne izvrstne rezultate. (Kern 2010, str. 198)

Organizacije morajo pri svojem delu biti inovativne, iznajdljive, usmerjene v nove izdelke, vztrajne, odločne in stalno naravnane k izboljšavi. (Škafar, 2018, str. 93; Krajšnik, 2017, str. 5)

Organizacije, ki so na trgu med uspešnejšimi organizacijami, ne uporabljajo samo modela odličnosti EFQM, uporabljajo tudi ostala orodja. (Mekiš, 2016, str. 131)

Za uspešnost je potrebno uskladiti vse formalne in neformalne sisteme (Epstein \& Rejc, 2014, str. 306).

Z raziskavo in interpretacijo ugotovitev, sporočil izbranih avtorjev kateri so bili vključeni v raziskavo, potrjujemo v vseh segmentih, da organizacije katere uporabljajo EFQM model so boljše v poslovni odličnosti.

Odlične organizacije ob uporabi modela EFQM uporabljajo tudi druga orodja kakovosti, ki pripomorejo k uspešnosti in odličnem rezultatu. Se hitreje in lažje prilagajajo trgu, lažje obdržijo ter pridobijo deležnike.

Organizacije, ki imajo vpeljan model EFQM in vzporedno uporabljajo različna orodja kakovosti so uspešnejša in bi prakso priporočila naprej. Poudariti je vseeno potrebno, da pa orodja kakovosti le niso v celoti izkoriščena tako kot bi lahko bila. Ponovno potrjujemo, da je na menedžmentu kako menedžerji vidijo in vodijo organizacijo do odličnosti, ki so jo deležni vsi deležniki in organizacije. 
Revija za univerzalno odličnost / Journal of Universal Excellence,

GRADNIKI POSLOVNE ODLIČNOSTI

Članek / Article

Marec 2021, leto / year 10, številka / number 1, str. / pp. 69-83.

\subsection{Analiza gradnika trajno doseganje izvrstnih rezultatov}

V tabeli 5 je prikazan gradnik z naslovom trajnostno doseganje izvrstnih rezultatov, ki smo ga povzeli po FOŠmetru poslovne odličnosti. Gradnik opredeljuje, da »odlične organizacije dosegajo na svojem področju delovanja trajno izvrstne rezultate, ki izpolnjujejo tako kratkoročne kot dolgoročne potrebe vseh njihovih deležnikov« (Model odličnosti EFQM, 2013, str. 8).

Izbrani gradnik ima 9 podgradnikov, ki so prikazani v tabeli 5. Prikazane so tudi povprečne ocene za leto 2018, 2020 ter skupne ocene za leto 2018 in 2020.

Tabela 2. Temeljni gradnik model odličnosti EFQM - Trajno doseganje izvrstnih rezultatov

\begin{tabular}{|c|c|c|c|c|}
\hline & & $\begin{array}{l}\text { Povprečje } \\
2018\end{array}$ & $\begin{array}{l}\text { Povprečje } \\
2020\end{array}$ & $\begin{array}{l}\text { Skupno } \\
2018 \text { in } \\
2020\end{array}$ \\
\hline 1. & $\begin{array}{l}\text { Zbirajo potrebe in pričakovanja deležnikov kot vhodne podatke za } \\
\text { razvoj in pregledovanje svoje strategije in podpornih politik, pri } \\
\text { tem pa so pozorne na vsako spremembo. }\end{array}$ & 4,05 & 3,90 & 3,94 \\
\hline 2. & $\begin{array}{l}\text { Prepoznavajo in razumejo ključne rezultate, potrebne za } \\
\text { uresničenje svojega poslanstva, ter ovrednotijo napredek glede na } \\
\text { svojo vizijo in strateške cilje. }\end{array}$ & 4,05 & 4,06 & 4,06 \\
\hline 3. & $\begin{array}{l}\text { Določijo in uporabljajo uravnotežen nabor rezultatov za } \\
\text { pregledovanje napredka, zagotavljajo pregled nad dolgo in } \\
\text { kratkoročnimi prednostnimi nalogami ter obvladujejo pričakovanja } \\
\text { ključnih deležnikov. }\end{array}$ & 4,15 & 4,10 & 4,12 \\
\hline 4. & $\begin{array}{l}\text { Sistematično udejanjajo in širijo strategijo in podporne politike, da } \\
\text { bi dosegli želeni nabor rezultatov, z jasno določenimi vzročno- } \\
\text { posledičnimi povezavami. }\end{array}$ & 4 & 3,86 & 3,90 \\
\hline 5. & $\begin{array}{l}\text { Postavljajo cilje na podlagi primerjav svojega delovanja z drugimi } \\
\text { organizacijami, na podlagi svojih sedanjih in potencialne } \\
\text { organizacijske sposobnosti ter na podlagi svojih strateških ciljev. }\end{array}$ & 4 & 3,94 & 3,96 \\
\hline 6. & $\begin{array}{l}\text { Ovrednotijo nabor doseženih rezultatov, da bi izboljšali uspešnost } \\
\text { delovanja v prihodnosti in zagotovili trajne koristi vsem svojim } \\
\text { deležnikom. }\end{array}$ & 4,15 & 3,90 & 3,97 \\
\hline 7. & $\begin{array}{l}\text { Pri deležnikih dosegajo visoko raven zaupanja z uporabo uspešnih } \\
\text { mehanizmov za razumevanje prihodnjih scenarijev ter uspešno } \\
\text { obvladovanje strateškega, operativnega in finančnega tveganja. }\end{array}$ & 4,05 & 3,92 & 3,96 \\
\hline 8. & $\begin{array}{l}\text { Zagotavljajo transparentnost pri finančnem in nefinančnem } \\
\text { poročanju relevantnim deležnikom, vključno z ustreznim organom } \\
\text { upravljanja, v skladu z njihovimi pričakovanji. }\end{array}$ & 4,1 & 4 & 4,03 \\
\hline 9. & $\begin{array}{l}\text { Svojim voditeljem zagotavljajo točne in zadostne informacije v } \\
\text { podporo pri njihovem pravočasnem odločanju. }\end{array}$ & 4,1 & 4,02 & 4,04 \\
\hline & SKUPNO & 4,07 & 3,97 & 4,00 \\
\hline
\end{tabular}

Opomba. Povzeto in prirejeno iz FO ̌́meter poslovne odličnosti: Preglednica ocen.

Z najboljšo povprečno oceno v letu 2018, 2019 ter skupno oceno 2018 in 2020, je označen podgradnik 3, ki govori, da se »določijo in uporabljajo uravnotežen nabor rezultatov za 
pregledovanje napredka, zagotavljajo pregled nad dolgo in kratkoročnimi prednostnimi nalogami ter obvladujejo pričakovanja ključnih deležnikov« (Model odličnosti EFQM, 2013, str. 8). Kar pomeni, da obvladujejo vse deležnike. Toda povprečne ocene se lahko hitro spremenijo. Skozi oceno je zaznati majhen upad v letu 2020.

Dobre povprečne ocene za leto 2018 so ravno tako zabeležene v podgradniku 6. Kar nakazuje, da so v letu 2018 »izboljšali uspešnost delovanja ter zagotovili trajnostno korist vsem svojim deležnikom« (Model odličnosti EFQM, 2013, str. 8). Povprečne ocene za leto 2020 se niso nadaljevale, ocene padejo za 0,25 .

Najslabše je ocenjen podgradnik 4. Povprečna ocena v letu 2020 pade za 0,14. Ocenjujemo, da ne dobro »udejanjajo in ne dobro širijo strategijo in podporno politiko, da bi dosegli želeni nabor rezultatov, z jasno določenimi vzorčno-posledičnimi povezavami« (Model odličnosti EFQM, 2013, str. 8).

Povprečna ocena v letu 2018 za podgradnik 5 je boljša za 0,6 v primerjavi z letom 2020. Toda vseeno najslabše ocenjena $v$ letu 2018. Vrednotimo, da se ne, "postavljajo cilji na podlagi primerjav z drugimi organizacijami, na podlagi svojih sedanjih in potencialno organizacijskih sposobnostih ter na podlagi svojih strateških ciljev« (Model odličnosti EFQM, 2013, str. 8).

Na prvi pogled je videti, da so ocene relativno visoke kar sledi, da si organizacije s pomočjo meril in orodij pomagajo doseči trajno odlične rezultate. Doseganje rezultatov v letu 2018 je za spoznanje bolje ocenjeno v primerjavi z letom 2020. Vse ocene so v razponu desetinke ali dve kar je še vedno dobro, seveda pa povprečje posledično pada.

Potrebno je ugotoviti zakaj ocene padajo. Podatki so zajeti v periodi dveh let. V kolikor v letu 2022 v primerjavi z letom 2020 ponovno padejo za desetinko se lahko to pozna pri trajno doseganju izvrstnih rezultatov. Za odlično poslovanje so vključeni vsi deležniki. Vedno pa se začne pri menedžmentu. Zato ocenjujemo, da se $\mathrm{v}$ začetku preveri vodenje organizacije in potem naprej. Po pregledu se ponovno uporabi Model odličnosti EFQM. Ker je v pripravi Model odličnosti EFQM 2020 se v nadaljevanju uporabi le tega.

Za doseganje trajnih rezultatov svetujemo, da se kot celota preveri druge gradniki s podgradniki in naredi primerjava ter konsistentnost med njimi. Na podlagi celote se nato poda ustrezne ukrepe.

\section{Zaključek}

Raziskava potrjuje skozi pregled številnih literatur in dobrih praks, da je eden izmed najbolj pomembnih vidikov organizacije ravno vodenje. Skozi dobro zasnovano vodenje se organizacije pravočasno odzovejo na spremembe zahtev tržišča. 
Preučevanje modela odličnosti EFQM s poudarkom na zadnjem gradniku, ki govori o trajnem doseganju izvrstnih rezultatov spoznamo, kako pomembno vlogo ima voditeljstvo.

$\mathrm{Z}$ dobrim vodenjem so organizacije odločno in nenehno usmerjene $\mathrm{k}$ inovativnosti, iznajdljivosti, vztrajnosti ter skozi povratno zanko širijo bazo znanja in izpopolnjujejo poslovanje.

Delovanje organizacije je potrebno gledati v širšem pomenu. Dodana vrednost poslovanja organizacij je v odnosu do družbe, okolja, gospodarstva in navsezadnje do organizacije same. Organizacije se morajo zavedati, da so spremembe stalnica in $\mathrm{v}$ kolikor se podjetje pravočasno odzove in prilagodi je uspeh-rezultat odličen. Vsekakor pa za odličnost mora organizacija pogledati na sam vrh voditeljstva, v globino in biti zrela za ta pristop. Voditi z vizijo, inspiracijo in integriteto je cilj in uspeh, ki se odraža na trajno doseganje izvrstnih rezultatov. Dinamična okolja zahtevajo dinamične sisteme, procesov podjetij, ki so ključ na katerem je vredno graditi.

Raziskava je bila omejena na zadnjo temeljno načelo, Trajno doseganje izvrstnih rezultatov, ki je odraz vseh ostali načel. Vsekakor bi bilo zanimivo preučiti preostala načela ter nadgraditi raziskavo na celoten model EFQM 2013. V objavi je ravno tako model EFQM 2020, ki je v preizkusnem obdobju in ni bil predmet raziskave in primerjave $\mathrm{z}$ aktualnim modelom FQM 2013. Kot naslednja omejitev raziskave je bila, delno povzemanje samoocenitve matičnih organizacij udeležencev poletne šole FOŠ v letu 2020.

Model EFQM 2013 je bil z letom 2020 deležen sprememb. Zanimivo bi bilo preučiti razlike, prednosti ter slabosti med modeloma EFQM 2013 ter EFQM 2020. Spremembe vsekakor so, kako jih najbolje uporabiti in implementirati v organizacijo. 
Revija za univerzalno odličnost / Journal of Universal Excellence,

GRADNIKI POSLOVNE ODLIČNOSTI

Članek / Article

Marec 2021, leto / year 10, številka / number 1, str. / pp. 69-83.

\section{Reference}

1. Bertoncelj, A., Bervar, M., Meško, M., Naraločnik, A., Nastav, B., Roblek, V., \& Trnavčević, A. (2015). Trajnostni razvoj. Ljubljana: GV založba.

2. Bower, L. J., \& Gilbert, G. C. (2011). How managers' everyday decisions create or destroy your company's strategy. Pridobljeno na: https://www.coursehero.com/file/38830864/Howmanagersdocx/

3. Colarič, G. (2019). Model dejavnikov trajnega doseganja odličnih rezultatov. Revija za univerzalno odličnost. 8(3), 259-270.

4. EFQM (2020a). The EFQM model. Brussels, EFQM.

5. EFQM (2020b). How is the EFQM Model 2020 development doing? (2020, 15. december). Pridobljeno na https://www.efqm.org/index.php/2019/05/10/how-is-the-efqm-model-2020development-doing/

6. EFQM European Fundation for Quality management (2020, 15. december). Pridobljeno na https://www.efqm.org/index.php/efqm-model/

7. Epstein, J. M., \& A. Rejc, B. A. (2010). Solving the sustainability implementation challenge. Organizational Dynamics, 39, 306-315. doi: 10.1016/j.orgdyn.2010.07.003

8. FOŠ, (2020). FOŠmeter poslovne odličnosti: Preglednica ocen. (Interno gradivo). Novo mesto: Fakulteta za organizacijske študije v Novem mestu.

9. Jazbec, P. (2012). Kakovost poslovanja izbranega podjetja-študija primera. (Diplomska naloga). Koper: Univerza na primorskem, Fakulteta za management. UDK: 005.336.3:303.433.2(043.2)

10. Jurša, K. (2015). Dejavniki odličnosti po modelu EFQM v izbrani banki. (Magistrska naloga). Koper: Univerza na primorskem, Fakulteta za management. UDK: 005.6:336.711(043.2)

11. Kern, P. K. (2010). Vpliv stalnih izboljšav in človeškega kapitala na poslovno odličnost organizacije. (Doktorska disertacija). Maribor: Univerza v Mariboru, Fakulteta za organizacijske vede. UDK: 005:005.336.3 (374.4) (043.3)

12. Krajišnik, U. (2017). Ocenjevanje odličnosti poslovanja univerz v republiki Sloveniji. (Magistrsko delo). Maribor: Univerza v Mariboru, Fakulteta za logistiko. [COBISS.SI-ID - 512843069]

13. Lazič, A. (2019). Ustvarjanje trajnostne prihodnosti organizacije. Revija za univerzalno odličnost. 8(1), 99-109.

14. Mekiš, A. (2016). Zavzetost zaposlenih in poslovna odličnost. (Magistrsko delo). Maribor: Univerza v Mariboru, Fakulteta za organizacijske vede. [COBISS.SI-ID - 7651091]

15. Miklavčič, M., \& Rusjan, B. (2018). Vloga in pomen meril voditeljstva in ravnanja z zmožnostmi zaposlenih v modelu EFQM. Izbrane teme organizacije in managementa. (Monografija).

Ljubljana: Društvo slovenska akademija za management. 2017. ISBN 978-961-92878-8-0

16. Model odličnosti EFQM (2013). Slovenski prevod brošure «EFQM Excellent model 2013«. Ljubljana: Ministrstvo za gospodarski razvoj in tehnologijo, Urad RS za meroslovje (MIRS).

17. Povšnar, M. (2014). Dejavniki kakovosti storitev in zadovoljstva uporabnikov: študija primera v izbrani banki. (Magistrska naloga). Koper: Univerza na primorskem, Fakulteta za management. UDK:005.336.3:336.71(043.2)

18. Rejc, B, A., Hren, A., Fink, T., \& Savič, N. (2018). Trajnostne poslovne strategije in trajnostni poslovni modeli v slovenski praksi (priročnik). SPIRIT Slovenija, javna agencija.

19. Škafar, B. (2018). Sistem vodenja kakovosti in modeli odličnosti: ključni dejavniki (ne)uspešnega delovanja. (Monografija). Novo mesto: Fakulteta za organizacijske študije v Novem mestu.

[COBISS.SI-ID=296310784] 
Marec 2021, leto / year 10, številka / number 1, str. / pp. 69-83.

20. Škedelj, J. (2016). Vodenje proizvodnje z uporabo modela odličnosti EFQM. Revija za univerzalno odličnost. 5(3), 251-260.

21. Slovenska kakovost (2020, 14. november). Model odličnosti EFQM. Pridobljeno na: http://slovenska-kakovost.si/storitve/efqm/

22. Štrukelj, T., Krajnović, A., \& Peša, A. (2015). Strateški management za sodobno poslovanje podjetja. Current Trends and Future Prospects in Entrepreneurship: Book of Full Papers, $5^{\text {th }}$ South-East European (SEE) meeting \& scientific conference of management departments, Varaždin, 23th-26th September 2015. Faculty of Organization and Informatics Varaždin, University of Zagreb. 2017.

23. Urad RS za meroslovje (2017). Analiza področja poslovne odličnosti v Republiki Sloveniji. Pridobljeno na https://www.podjetniskiportal.si/uploads/gradiva/poslovna_odlicnost/strategija/s_analiza_poslovna_odlicnost_sprejeti_po pravki-koncna.pdf

24. Varl, T. (2018). Ključni kazalniki uspešnosti v proizvodnih podjetjih. (Delo diplomskega projekta). Maribor: Univerza v Mariboru, Ekonomsko-poslovna fakulteta.

***

Dejan Medic po izobrazbi diplomirani strojni inženir. Dolgoletne delovne izkušnje v različnih podjetij na področju strojništva in kakovosti. Trenutno zaposlen v podjetju I.H.S. d.o.o. kot vodja kakovosti. Na Fakulteti organizacijske študije v Novem mestu nadaljuje podiplomski študij Menedžment kakovosti.

$* * *$

Sandra Medic po izobrazbi diplomirani varnostni inženir. Zaposlena v Krki, d.d., Novo mesto kot strokovna delavka za varnost in zdravje pri delu. Pred zaposlitvijo v Krki, d.d., Novo mesto opravljala strokovne naloge v različnih podjetjih kot zunanja strokovna delavka za varnost in zdravje pri delu. Na Fakulteti organizacijske študije v Novem mestu nadaljuje podiplomski študij Menedžment kakovosti.

\section{Abstract: \\ Sustaining Outstanding Results}

Research Question (RQ): How do excellent organizations achieve and maintained outstanding results?

Purpose: To determine what criteria and approaches we should use to achieve lasting excellent results in order to maintain excellent results.

Method: A qualitative method of reviewing domestic and foreign literature as well as good practices was used for the study.

Results: The research confirmed that outstanding results are permanently maintained considering all factors and the people involved according to the EFQM model of excellence.

Organization: Leaders develop, define, collaborate, strengthen, and ensure successful management of change in operations of the organizations.

Society: Great organizations provide and maintain excellent results that satisfy both the external and the internal stakeholders. 
Revija za univerzalno odličnost / Journal of Universal Excellence,

GRADNIKI POSLOVNE ODLIČNOSTI

Marec 2021, leto / year 10, številka / number 1, str. / pp. 69-83.

Originality: Regardless of the activity they perform, organizations will use the tools and models of business excellence to achieve and maintain their excellence.

Limitations/Further Research: The research can be upgraded to other fundamental concepts EFQM model and use it in practice as an implementation of EFQM 2013 model of excellence in the organization. In the following, the research could be extended to the EFQM 2020 model

Keywords: EFQM excellence model, fundamental concepts of excellence, criteria, enablers, results, stakeholders, integrity.

Copyright (c) Dejan MEDIC, Sandra MEDIC

\section{(c) (†) (?)}

Creative Commons License

This work is licensed under a Creative Commons Attribution-ShareAlike 4.0 International License. 